\title{
Stimuli-Responsive Drug Release from Smart Polymers
}

\author{
Carlos M. Wells* (D), Michael Harris, Landon Choi, Vishnu Priya Murali, \\ Fernanda Delbuque Guerra and J. Amber Jennings ${ }^{(1)}$ \\ Department of Biomedical Engineering, The University of Memphis, Memphis, TN 38152, USA \\ * Correspondence: cwells3@memphis.edu; Tel.: +1-1901-289-9827
}

Received: 28 May 2019; Accepted: 26 July 2019; Published: 31 July 2019

check for updates

\begin{abstract}
Over the past 10 years, stimuli-responsive polymeric biomaterials have emerged as effective systems for the delivery of therapeutics. Persistent with ongoing efforts to minimize adverse effects, stimuli-responsive biomaterials are designed to release in response to either chemical, physical, or biological triggers. The stimuli-responsiveness of smart biomaterials may improve spatiotemporal specificity of release. The material design may be used to tailor smart polymers to release a drug when particular stimuli are present. Smart biomaterials may use internal or external stimuli as triggering mechanisms. Internal stimuli-responsive smart biomaterials include those that respond to specific enzymes or changes in microenvironment $\mathrm{pH}$; external stimuli can consist of electromagnetic, light, or acoustic energy; with some smart biomaterials responding to multiple stimuli. This review looks at current and evolving stimuli-responsive polymeric biomaterials in their proposed applications.
\end{abstract}

Keywords: stimuli-responsiveness; drug release; drug delivery; thermo-responsive materials; enzyme-responsive materials; $\mathrm{pH}$-responsive materials; shape-memory materials

\section{Introduction}

Researchers throughout different disciplines continue to explore improved and safer ways to locally deliver drugs to specific sites of action, attempting to increase specificity and efficacy. Over the years, numerous investigations on biomaterials have seen successes in the development of controlled delivery systems $[1,2]$. These achievements have been the results of interdisciplinary contributions across chemistry, biology, physics, and pharmacology, and with inputs from clinicians. Biomaterials have evolved to cover vast libraries, with diverse chemical structures, varied morphologies, and numerous physiological functions. Synthetic polymers, biomacromolecules, nano-/micro-particles, biocompatibility, biodegradability, specific targeting, cargo protection, and bulk materials are some of the developments that have improved or enhanced biomaterials, their applications, or the combination [3]. Drug carriers and their subsequent on-demand release have been the benefactors from flexible designs that evolved to address the perplexing and diverse physiological environment.

Smart biomaterials are the next evolutionary step in optimizing patient-centric care while potentially providing treatment options previously not available. Smart biomaterials possess tailor-designed stimuli-responsiveness that attempts to address many issues where current drug delivery systems are lacking [4]. The incorporation of different internal stimuli from the physiological microenvironment, such as $\mathrm{pH}$, redox, temperature, enzyme, and mechanical force, or some readily available and relatively easily-controlled external stimuli, e.g., light, ultrasound, electric, and magnetic, has led to highly controlled smart systems [3]. The spatiotemporal control that many smart systems possess increases efficacy, and minimizes potential side effects and off-target toxicity.

The emphasis of this mini-review is to present and analyze progress in the development of polymeric smart drug delivery biomaterials within the past decade. We will focus on three primary 
categories for stimuli-responsive polymeric systems, chemical, physical, and biological, with systems containing multiple or overlapping stimuli-responsiveness discussed separately. Within each group, this mini-review will discuss $\mathrm{pH}-$, acoustic-, photo-, magnetic-, electric-, and enzyme-responsiveness as distinct subcategories; a summary of the reviewed studies in tabulated form is present at the conclusion (Table 1). We will survey representative samples for each of the subcategory stimuli types with appropriate advantages, disadvantages, challenges, and future directions.

\section{Chemical Stimuli-Responsive Systems}

\section{pH-Responsiveness}

Smart biomaterials can be designed to respond to alterations in environmental parameters, promoting the delivery of therapeutics locally when the environmental $\mathrm{pH}$ is either acidic or basic, and allowing for a release in particular organ systems or pathological conditions in which the $\mathrm{pH}$ changes. For the delivery of highly toxic chemotherapeutics, $\mathrm{pH}$-controlled release systems can limit systemic concentrations of drugs [2,5-9]. The acidic extracellular environment of solid tumors makes it possible to develop pH-sensitive drug delivery systems that undergo physical/chemical changes or both when exposed to acidic $\mathrm{pH}$. Apart from cancer therapy, smart delivery systems explore other diseases, such as gastric ulcers [10], osteomyelitis [11], and diabetes [12]. Generally, polyelectrolyte polymeric systems contain weak acidic or basic groups in the polymer backbone. Changes in environmental $\mathrm{pH}$ trigger the acceptance or release of protons, promoting cleavage of bonds, solubility, and or structure.

Materials with $\mathrm{pH}$-responsiveness have been synthesized and studied in a variety of forms, such as hydrogels [6,10,12], nanoparticles [2,8,13,14], beads [15], hollow particles [11], and 3D porous structures [16]. In a recent study, Qu et al. investigated N-carboxyethyl chitosan and dibenzaldehyde-terminated poly(ethylene glycol) (PEG) encapsulated with doxorubicin (DOX) as an injectable hydrogel for hepatocellular carcinoma therapy [6]. The study demonstrated how changes in $\mathrm{pH}$ promote chemical and physical modifications to swell the polymeric system, which causes the release of the encapsulated drug. Using a similar concept, Li et al. fabricated fluorescent boronate nanoparticles encapsulated with DOX for intracellular imaging and suppression of a cancer cell line, Michigan Cancer Foundation-7, commonly referred to as MCF-7 [2]. In their study, the system was created based on the formation of a boronic ester link between two different acid-cleavable modified poly(lactic acid)-poly(ethyleneimine) (PLA-PEI) copolymer moieties, boronic acid, and a diol. These biomaterials demonstrated a burst release of DOX after a minimal initial release upon a $\mathrm{pH}$ shift from 7.4 to 5.4. Representative polymeric systems and their $\mathrm{pH}$-responsiveness can be seen in Figure 1 [17].

In a different approach, a group investigated the use of sodium bicarbonate inside poly(lactic-co-glycolic acid) (PLGA) hollow microspheres [11]. Instead of acid-cleavable bonds stimulating response, this system relied on a chemical reaction within the delivery system, which yields by-products that stimulate a change in the morphology of the material encapsulating the drug. In acidic conditions, bicarbonate generates $\mathrm{CO}_{2}$ and water from the decomposition of the carbonic acid, building the gas pressure to burst the PLGA shell and thus release the encapsulated antibiotic. Similarly to cancerous tissues, inflamed tissues have a lower $\mathrm{pH}$, and therefore, the $\mathrm{pH}$-sensitive release has advantages for infection therapy. The authors reported that in a preclinical model, infections were successfully cured only in the group that used the $\mathrm{pH}$-sensitive material for antibiotic delivery.

Other research has explored materials that are sensitive to higher $\mathrm{pH}$ levels to target organs, such as the lower intestine. In a study reported by Pafiti et al., hydrogels composed of collapsed hollow particles entrapped within a poly(acrylamide) network demonstrated disintegration and drug release at $\mathrm{pH} 8.0$ [18]. This $\mathrm{pH}$-sensitive material was capable of maintaining its initial morphological properties in the stomach $(\mathrm{pH}<4.0)$ and promoted the release of a drug due to the disintegration of the collapsed hollow particles in high $\mathrm{pH}$.

Polymeric materials with $\mathrm{pH}$-responsiveness have demonstrated tailoring for specific applications. $\mathrm{pH}$-responsive polymers allow physicochemical features, such as the degradation rate, solubility, 
flexibility, injectability, adhesion, and mechanical strength, to be modulated. Furthermore, the ability to produce polymeric biomaterials in different forms and shapes allows for the administration of these systems in a variety of methods, including intravenous, intraosseous, subcutaneous, ingestion, and transdermal. A disadvantage of $\mathrm{pH}$-responsive systems requires that the environmental $\mathrm{pH}$ may vary depending on the severity of disease or proximity to diseased tissue and maintaining structure during the process of delivery may be challenging. $\mathrm{pH}$-sensitive systems may be activated during implantation or administration, making these systems susceptible to off-target delivery. Overcoming these disadvantages concurrent with progress on the existent advantages provides room for future research, development, and improvements in $\mathrm{pH}$-responsive polymers for drug delivery.

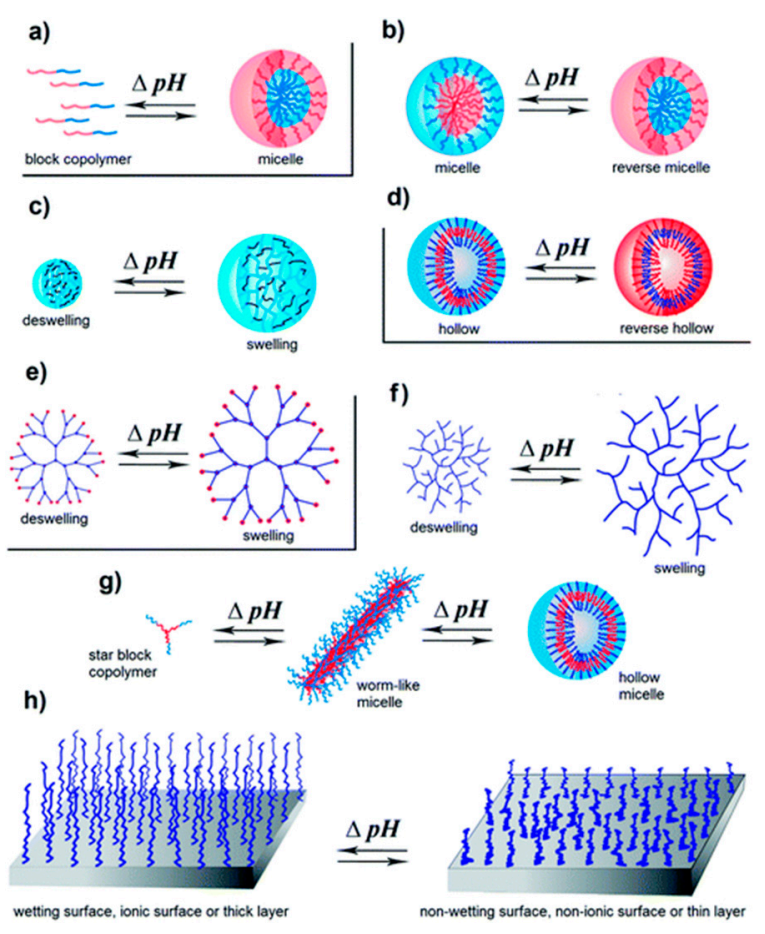

Figure 1. pH-responsive polymers of different architectures: (a) unimer-micelle, (b) micelle-reverse micelle, (c) nanogels or microgels, (d) hollow-reverse hollow, (e) dendrimer, (f) hyper-branched, (g) micelle morphology changes (from worm-like to hollow), and (h) polymer brushes. Reprinted with permission from Polymer Chemistry, 2017, 8, 144-176. Copyright (2017) The Royal Society of Chemistry.

\section{Physical Stimuli-Responsive Systems}

\subsection{Acoustic-Responsiveness}

Through the incorporation of microarchitecture and steric hindrance, PEGylated gold-nanoparticles encapsulated within calcium cross-linked alginate microbeads hydrogels have been investigated for their ability to release bone morphogenetic protein-2 conjugated gold nanoparticles through an "on/off" switch [19]. The use of ultrasound (U/S) led to a six-fold increase in the cumulative release of PEGylated gold nanoparticles compared to the use of no stimuli (diffusion), with the demonstration of repeatability of acoustic stimuli-responsiveness [19]. Huebsch et al. designed a similar system for an injectable digital drug release involving the use of ultrasound to trigger the release of the cancer therapeutic mitoxantrone encapsulated in cross-linked self-healing alginate hydrogels [20]. This study found that pulsed stimulation outperformed constant ultrasound. These cross-linked alginate systems implanted into xenograft tumors in mice were more sensitive to short-term, high-dose "bursts" of the chemotherapeutic mitoxantrone than to continuous doses over more extended periods [20]. 
Several systems make use of capsules or bubbles to enable acoustic responses due to cavitation. Zhou et al. investigated biocompatible chitosan nanobubbles (NBs) suitable for U/S-targeted DOX delivery, showing significant increases in DOX release after ultrasound stimulation for its noninvasive release profile. The in vitro release profile of the DOX-NBs in the U/S group had released a substantial amount of the encapsulated DOX compared to the non-U/S group, and nearly twice as much after $24 \mathrm{~h}$ [21]. Yang et al. designed uniform biodegradable nanocapsules to form a three-in-one theranostic nanoplatform. In this system, perfluorohexane was encapsulated by DOX-loaded poly(methacrylic acid) (PMAA) shells with disulfide cross-linkage for ultrasound readings and drug release (Figure 2) [22]. A combination of acidic $\mathrm{pH}$ exposure to glutathione and ultrasound stimulation resulted in an increased release [22]. Nguyen et al. produced stable nanodroplets that release simvastatin for degenerative disc disease that can undergo multiple exposures of high-intensity focused ultrasound (HIFU) for possible long-term treatment. Compared to the control exposure (sham), the U/S-treatment doubled the drug release and exhibited a consistent drug release with each U/S-exposure [23].

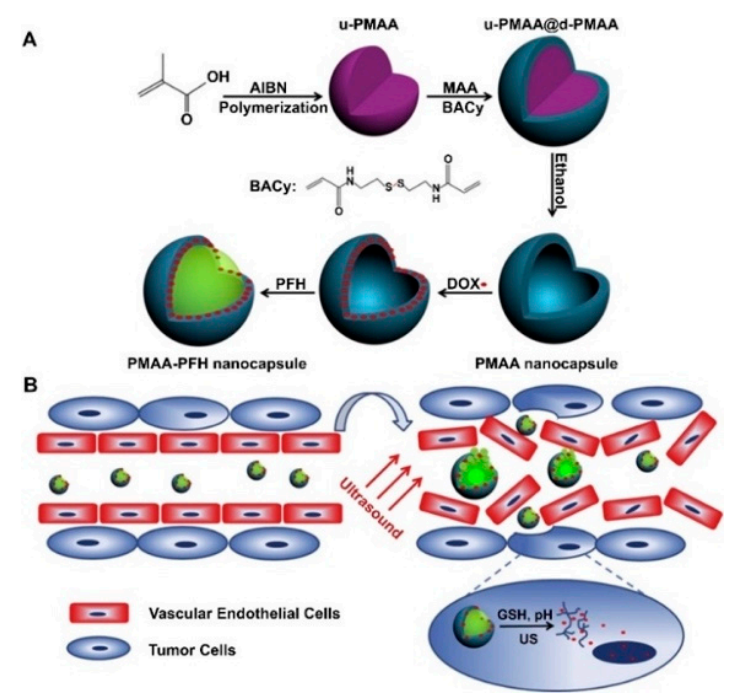

Figure 2. (A) Schematic representation of the preparation of doxorubicin loaded poly(methacylate acid)-perfluorohexane (PMAA-PFH) nanocapsules. (B) Schematic procedure for imaging-guided ultrasound triggered drug delivery to tumors using biodegradable PMAA-PFH nanocapsules. Reprinted with permission from Biomaterials, 2014, 35(6), 2079-2088. Copyright (2014) Elsevier Ltd.

Cao et al. devised phase-changeable materials composed of lipid-base and PLGA nanodroplets that release DOX and perfluoropentane when triggered by low-intensity focused ultrasound (LIFU) to improve anticancer drug delivery [24]. The nanodroplets demonstrated improved inhibition of tumor proliferation over materials not treated with LIFU, leading to enhanced animal survival [24]. Increasing the number of pulses improved the animal survival rate compared to a single burst of LIFU; an increase in vascular permeability of tumors was additionally observed [24]. Salgarella et al. investigated the synthesis and evaluation of five different forms of poly(2-oxazoline) micelles for a possible carrier of a drug delivery system triggered with ultrasound [25]. Micelles were tailored by controlling the ratio of hydrophilic and hydrophobic block copolymers and exhibited a significant release of dexamethasone. Gai et al. developed free-standing biocompatible polylactic acid (PLA) nanoand micro-chamber arrays using two different methods for encapsulation, one-step dip-coating and microcontact printing of air, $\mathrm{NaCl}$, and rhodamine $\mathrm{B}$ dye [26]. This work showed that the formation of microchambers can provide long-term encapsulation of small hydrophilic molecules and the release profiles of the microchambers with and without the use of HIFU [26]. With the use of HIFU treatment, the microchambers release around four times the amount of the group without the HIFU treatment [26].

The utilization of acoustic-responsive systems provides efficient drug release and controlled elution based upon the composition of the carriers before and after the use of high- or low-frequency 
ultrasound. Ultrasound as a stimulus for drug delivery may use readily available equipment and is relatively noninvasive. There may be limitations in how deep within tissue the ultrasound can penetrate; with an ongoing need to investigate how to deliver the materials to targeted tissues before stimulation. Exploration of pulsed vs. constant stimulation could enable further tailoring of targeted therapies with new diagnostic qualities.

\subsection{Photo-Responsiveness}

Light-responsive biomaterials have been an attractive option for the controlled release of drugs and other therapeutic molecules, as they can be induced non-invasively with high spatial and temporal precision $[27,28]$. Such biomaterials reduce the overall systemic dosage of the drug, thereby reducing the side effects and providing prolonged action at the target site [29,30]. Most commonly used light-responsive agents include spiropyrans (SP) and azobenzenes (Azo) [28,31]. Hydrophobic SP upon ultraviolet (UV) irradiation reversibly changes from its nonionic form to a hydrophilic polar isomer called merocyanine, which reverts to SP upon exposure to visible light [32-34]. Azo is another photo-responsive agent, which switches reversibly from its more stable and apolar trans-state to a more polar cis state upon UV irradiation [28,35]. Reversion induction occurs by more prolonged wavelength exposure or thermal relaxation [35].

Ultraviolet light has been commonly used to induce drug release in light-responsive biomaterials since these biomaterials mostly respond to shorter wavelengths of light. Kim et al. used SP to synthesize hyperbranched polyglycerol micelles, which could be used to load and release therapeutics in a site-specific and time-controlled manner (Figure 3) [34]. Upon UV exposure, SP photo-isomerized to hydrophilic merocyanine, causing the disassembly of the micelle and stimulating the controlled release of model hydrophobic drugs. Merocyanine reverted to SP upon visible light exposure [34].

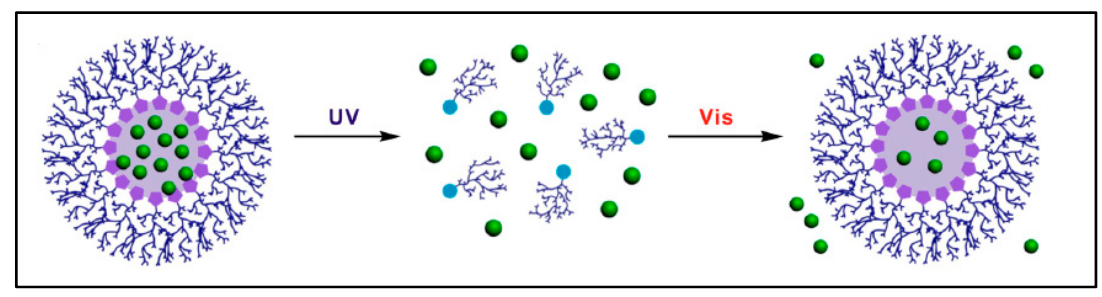

Figure 3. Illustration of model drug (green spheres) release upon $254 \mathrm{~nm}$ UV irradiation and re-encapsulation upon $620 \mathrm{~nm}$ visible irradiation of spiropyrans-hyperbranched polyglycerol micelles. Reprinted with permission from Biomacromolecules 2014, 15, 628-634. Copyright (2014) American Chemical Society.

To develop targeted cancer drug delivery systems, Pearson et al. synthesized light-responsive glycopolymer micelles made of Azo and $\beta$-galactose units [36]. The galactose units were intended to target the galectin-3-receptors, overexpressed on melanoma cells. The Azo groups controlled the release of the hydrophobic model drug, attributed to copolymer disassembly. Hardy et al. developed a hydrogel-based "on-demand" micro-needle array transdermal drug delivery system, made from 2-hydroxyethyl methacrylate and ethylene glycol dimethacrylate as well as ibuprofen-loaded 3,5-dimethoxybenzene conjugate [37]. These microneedles containing the conjugate and drug were inserted in the skin and irradiated with UV light, stimulating cleavage of the conjugate and releasing ibuprofen as the microneedle array hydrogel swelled. In vitro, this system remained intact and delivered multiple doses of the drug upon application of an optical trigger [37]. To overcome the multidrug resistance (MDR) responsible for the low effectiveness of chemotherapeutics, Chen et al. developed light-responsive mPEG-PLGA nanoparticles that induced nitric oxide (NO) release when exposed to UV, which reversed the MDR of tumor cells, in addition to breaking open nanoparticle shells to release DOX [38]. 
Primary limitations of UV-stimulated release are poor tissue penetration and its damaging effects on healthy tissues [39]. To avoid them, scientists are shifting the focus towards developing near-infrared (NIR) or visible light-responsive material. Tian et al. developed a diselenide cross-linked polymethacrylic acid system loaded with DOX and indocyanine green [40]. Upon NIR irradiation, indocyanine green released reactive oxygen species, which cleaved the diselenide bond, disrupting the nanogel and releasing DOX. In the absence of NIR, meager amounts of DOX from the nanogels were released, contrasted with the maximum release and toxicity to cancer cells when irradiated with NIR [40]. Photodynamic therapy/photothermal therapy or both provides the basis for many NIR light-responsive systems. Liang et al. developed a hybrid nanoparticle system made up of an NIR light-responsive chromophore (DEACM), incorporated to $\beta$-cyclodextrins ( $\beta$-CD) with cRGD functionalized PEG and coordinated with DOX-loaded AuNRs [41]. On NIR light exposure, Au enhanced the photosolvolysis of DEACM and triggered the release of DOX. The system showed improved anti-cancer effect in vitro as well as in vivo [41]. An "on-demand" drug delivery system was developed based on polymer-nanostructure composite microneedles of polycaprolactone and NIR absorbing $\mathrm{LaB}_{6} @ \mathrm{SiO}_{2}$ reported by Chen et al. [42]. Upon NIR exposure, the $\mathrm{LaB}_{6} @ \mathrm{SiO}_{2}$ mediated a light to heat transduction, causing the melting of the microneedles, and releasing the model drug, rhodamine 6G dye [42]. Wang et al. developed tetra-ortho-methoxy substituted azobenzene (mAzo), which responded to red light instead of UV light [43,44]. Upon red light exposure, the compound underwent disassembly and a gel-to-sol transition, releasing model proteins. The drug release stopped when the red light was switched to blue light [44].

Photo-responsive biomaterials are practical options for the controlled release of therapeutics as they can be induced non-invasively with high precision, thereby increasing their action at the target site and reducing systemic toxicity. Current light sources in use and investigated include UV, visible, NIR, and lasers of various wavelengths. Despite recent progress, many light-responsive polymers have incredibly complicated and technique-sensitive synthesis processes, which limits their ability to be produced in bulk. Though NIR-responsive agents are gaining popularity over UV-responsive agents because of the inadequate tissue-penetrating ability of $\mathrm{UV}$, there are no studies that have investigated NIR-responsive agents in deep tissues. The few studies which have tested these agents in vivo have used only superficial disease models. Also, NIR light-responsive systems have lower efficiency and thereby would require a prolonged exposure time to produce a practical therapeutic effect, which may cause damage to the surrounding healthy tissue due to unwanted excessive heating. The focus is shifting toward biodegradable systems, with improved cytocompatibility and those that naturally degrade in the body once the loaded drug is released. Most of these studies have been carried out only in vitro. To better understand their translational potential, it is essential to continue development and confirm results in vivo.

\subsection{Magnetic-Responsiveness}

Magnetic stimulation is unique in that it can be used to target the drug delivery system, monitor the concentration and distribution of the system, and influence the rate drug release, enabling precise control over the location and rate of drug delivery. These materials typically contain $\mathrm{Fe}_{3} \mathrm{O}_{4}$ superparamagnetic iron oxide nanoparticles (SPIONs), which offer a favorable combination of biocompatibility and magnetic responsiveness. At sufficiently small sizes, typically $100 \mathrm{~nm}$ or less, iron oxide nanoparticles exhibit superparamagnetic behavior in which thermal fluctuations randomize the magnetic moment of the particles and eliminate residual magnetization that might trigger particle agglomeration in vivo [45]. Magnetic guidance can be accomplished using a series of permanent magnets placed around the exterior of the subject to create a magnetic field gradient that retains and removes SPIONS from the bloodstream. SPION stimulation with an alternating-current magnetic field (AMF) induces heat generation through Brownian losses, Neel relaxation, or both. This heat can be utilized to increase drug diffusion from the drug delivery system, induce conformational changes or pore formation in 
polymers surrounding the SPION, or break heat-labile covalent bonds to increase the rate of drug release on demand [45].

Clinical efficacy and safety of SPIONS have been demonstrated in vivo, with several clinical trials showing that magnetic stimulation of SPIONS was well-tolerated in vivo and could reliably maintain temperatures between 40 and $45^{\circ} \mathrm{C}$ in glioblastoma and prostate tumors [46,47]. SPIONS generate high local temperatures that decay exponentially with distance from the surface [48]; at sufficiently low concentrations, SPION hyperthermia can be used to drive drug release without significantly raising the temperature of the surrounding tissue. Recent studies have effectively measured the local temperature surrounding AMF-stimulated SPIONS and shown temperature increases of up to $50{ }^{\circ} \mathrm{C}$ at the surface $(<1 \mathrm{~nm})$ without significantly increasing the temperature of the surrounding media $[49,50]$. These findings suggest that SPION-based hyperthermia can be useful with heat-labile bonds or thermosensitive materials with critical temperatures above the threshold for hyperthermic tissue damage. For example, AMF can be used to induce a phase transition in SPION-loaded PLGA nanoparticles with a glass transition temperature $\left(\mathrm{T}_{\mathrm{g}}\right)$ of $42{ }^{\circ} \mathrm{C}$, thereby doubling the amount of DOX released compared to particles with higher $\mathrm{T}_{\mathrm{g}}$ (Figure 4) [51]. Riedinger et al. used varying lengths of polyethylene glycol to space a thermolabile azo linker at various distances from the surface of the SPIONs, achieving up to threefold increases in DOX elution when stimulated with AMF by tailoring the spacer length [48]. The use of varying spacer lengths in an SPION could theoretically be used to provide further fine-tuning of stimuli-responsiveness or create a different release profile for dual drug systems.

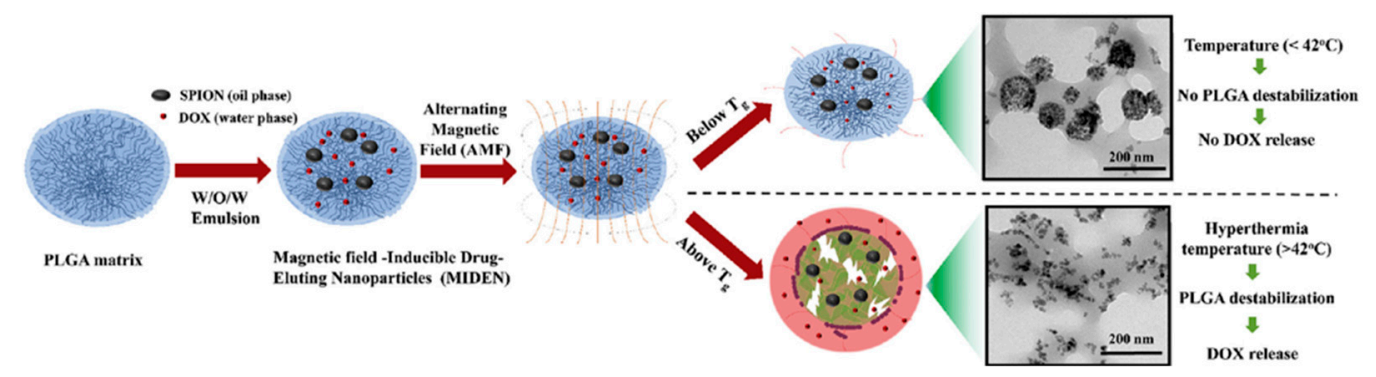

Figure 4. Schematic illustration showing the application of alternating-current magnetic field to induce a phase transition in poly(lactic-co-glycolic acid) nanoparticles and increase the release of a chemotherapeutic. Reprinted with permission from Biomaterials 2018, 180, 240-252. Copyright (2018) Elsevier Ltd.

The ability to externally modulate drug release is particularly advantageous as magnetic field generators can be used to increase the drug concentration for acute symptom flares. One particularly appealing application is the delivery of nonsteroidal anti-inflammatory drugs (NSAIDs), as patients would be able to self-treat acute flares of chronic musculoskeletal pain through SPION-mediated drug delivery, thereby reducing the need for opioid pain medications and repeat doctor visits $[52,53]$. In a murine model of analgesia, magnetic stimulation of ketorolac-loaded SPIONs provided a $50 \%$ increase in the duration of clinically assessed pain relief compared to non-stimulated particles, while both provided greater magnitude and duration of pain relief compared to ketorolac alone [52]. Another study by Duan et al. demonstrated that SPION-PEI nanoparticles loaded with siRNAs for Interleukin-2 and Interleukin-15 could be used to treat rheumatoid arthritis [54]. Stimulation with a neodymium magnet for two hours caused a significant increase in particle accumulation at the target joint, increased particle uptake into macrophages and T lymphocytes, and reduced cartilage destruction compared to unstimulated controls.

Furthermore, magnetic stimulation can be used to maintain drug elution rates as the carrier nears depletion. Mohapatra et al. demonstrated that brief magnetic stimulation of SPION-loaded chitosan-polyethylene glycol dimethacrylate microbeads could increase vancomycin elution to 
therapeutic levels $(>2 \mathrm{mcg} / \mathrm{mL}$ ) after drug release had dropped to negligible levels for three days $[55,56]$. This approach may be valuable as a means to reduce the dosing frequency.

\subsection{Electric-Responsiveness}

Electric stimuli-responsive systems are composed of electroactive polymers (EAPs), including polyaniline, polypyrrole, polythiophene, ethylene vinyl acetate, and polyethylene, that change shape, or volume upon stimulation with an electric current or a combination of both [57]. Alternating single and double bonds in the backbone of EAPs create a delocalized source of pi-bond electrons that can easily travel along the polymer chain, enabling the conduction of an electric charge [58]. Upon application of an electrical potential, EAPs will undergo reversible oxidation/reduction reactions that alter polymer charge, induce conformational changes, or both. The redox reactions are typically reversible, and many electro-responsive systems respond to repeat stimulation in a pulsatile on-off switch [59]. Ionic dopants are added during the polymerization process to control the initial redox state of the polymer and serve as ion carriers as the polymer charge changes during stimulation. Oxidation or reduction of the polymer may directly repel the drug payload, as with anionic ibuprofen, thereby increasing elution in response to stimulation [60,61]. Alternatively, the drug may bind to dopant molecules that carry it out of the polymer matrix upon stimulation, or the polymer undergoes conformation changes that allow increased diffusion [62].

EAPs typically suffer from inferior mechanical properties and are not biodegradable; therefore, many recent studies have incorporated EAPs into natural hydrogels or scaffolds to impart electro-responsive properties. For example, Atoufi et al. grafted aniline tetramers to alginate and combined the resulting EAP into agarose gels [59]. The resulting hydrogel had mechanical and biocompatibility properties comparable to typical agarose hydrogels but reproducibly released approximately $1.2 \%$ of the overall dexamethasone payload in response to three-minute stimulations with $-1 \mathrm{~V}$. Nano-scale conductive polymers have received increased interest due to their high drug binding efficiency and improved responsiveness to stimulation. Lee et al. created polypyrrole nanowire arrays from sacrificial alumina oxide templates. The resulting collection was found to adsorb $10 \times$ more DOX as bulk polypyrrole due to the increased surface area to volume ratio and exhibited pulsatile drug release when stimulated with $-1 \mathrm{~V}$ [62]. Additionally, Wang et al. have used redox-induced EAP conformation changes to create functionalized $\beta$-cyclodextrin electro-responsive gates for mesoporous silica nanoparticles [63]. The restraining of gemcitabine release to periods of stimulation with $-1.5 \mathrm{~V}$, demonstrated active holding of the gates in the open or closed position, achieving true on-off elution.

In addition to directly increasing drug release from conductive systems, electric stimulation can be used to enhance cellular uptake of drugs or nanoparticles in a process known as electroporation. Application of DC or AC electrical pulses can create transient pores (lasting $<15 \mathrm{~min}$ ) in the cellular membranes, blood vessels, and skin, facilitating the delivery of drugs, nanoparticles, or both $[64,65]$. These membrane pores allow drugs or nanoparticles to bypass acidic endosomal compartments altogether, improving the efficacy of drug delivery to the cytosol and alleviating requirements of the carrier to withstand/escape the acidic endosomal chamber [66]. By optimizing the properties of the electric stimulus, it is possible to create pores in the cellular membrane and liposomal drug carriers simultaneously, thereby using one stimulus to facilitate cellular entry and release the drug payload [67].

Electric stimulation provides a simple and inexpensive method of modulating drug release as clinicians deem necessary. EAPs can be used by themselves or incorporated into biocompatible polymers to create novel stimuli-responsive, biodegradable systems. The redox reactions driving stimuli responsiveness are reversible and reproducible, enabling reliable control over drug release from the system. The primary disadvantage of electric stimulation is the need to place electrodes in the polymer matrix, limiting use to topical or subdermal implants. However, the lack of specialized equipment and ease of use make electric stimulation well suited for use in these areas. 


\section{Biological Stimuli-Responsive Systems}

\section{Enzyme-Responsiveness}

Due to their outstanding ability to bio-recognize and catalyze physicochemical material changes, enzymes are useful in the design of smart biomaterials. Enzyme-based smart delivery systems are optimal in certain applications when there is an overexpression of specific enzymes in the tissue environment, a concentration gradient difference related to a diseased condition, or the combination. Some cancerous tissues have been shown to possess elevated levels of matrix metalloproteinases (MMPs) [68], which possess the ability to selectively cleave peptide bonds between nonterminal amino acids [69]. Enzyme-responsive materials possess advantages due to their specificities in cell regulation and activities related to the variety of their biological and metabolic roles [70-73]. Enzymes secreted with spatiotemporal control possess some structural features that increase substrate specificity [74]. Enzyme-responsive systems can protect their cargo from degradation during transport to the target and release with selectivity at the target site (Figure 5) [75]. Enzymatic substrates covalently linked to amphiphilic copolymers is a common strategy for fabricating enzyme-responsive polymer assemblies [76,77]. Nanomaterials made from enzyme-responsive materials have the added advantage of increased permeability and retention (EPR) effects and site-specific delivery $[78,79]$.

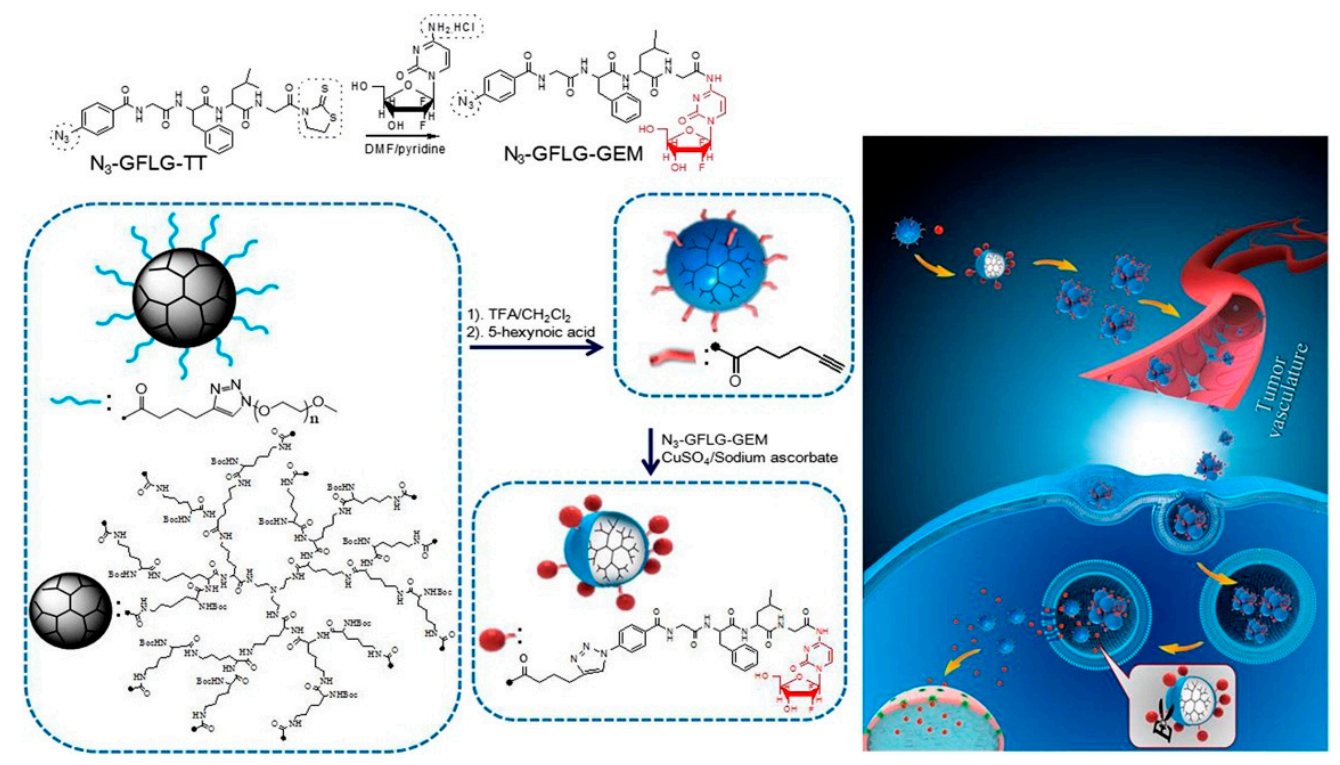

Figure 5. The scheme of preparing of lysine peptide dendrimer-glycly phenylalanyl leucyl glycine tetra-peptide-gemcitabine conjugate (Dendrimer-gemcitabine). The conjugate-based nanoparticles accumulate into the tumor via the EPR effect and enzyme-responsively release drugs. Reprinted with permission from Acta Biomaterialia, 2017, 55, 153-162. Copyright (2017) Elsevier Ltd.

The amount of DOX released from an enzyme-responsive pillararene-based polymer substituted macrocyclic amphiphile system significantly increased in the presence of L-asparaginase [80]. Another group investigated a pillararene-based polymer-substituted macrocyclic amphiphile PPMA to release DOX in response to L-asparaginase [80]. Nanoparticles composed of poly(D, L-lactic-co-glycolic acid)-block-polyethylene glycol copolymer, blended with a tumor-activated prodrug, composed of an MMP2-sensitive peptide conjugating DOX to PLGA, released higher amounts of DOX when incubated with MMP2 [81]. The targeting of enzymatic substrates allows for improved specificity while mitigating undesired off-target effects. Wang et al. worked to combine montmorillonite (MMT) and hyaluronic acid (HA) on the surface of biomaterials within a multilayer film for long-term biofilm inhibition [82]. The films released higher levels of gentamicin sulfate in the presence of HAS compared to PBS, with release levels being directly correspondent to the HAS concentration [82]. When exposed to Escherichia 
coli and Staphylococcus aureus infection microenvironments, the films' responsiveness to E. coli was higher [82].

Zhang et al. built an enzyme-responsive PEGylated system that was stimulated to release gemcitabine when exposed to Cathepsin B, which is expressed in the tumor microenvironment [75]. Cathepsin B presence or absence greatly influenced the amount of gemcitabine released [75]. Using layer-by-layer (LBL) composition, iron oxide nanoparticles coated with milk protein casein $(\mathrm{CN})$ and loaded with DOX were investigated for oral delivery (Figure 6) [83]. Huang et al. found that DOX release from the nanoparticles increased as their exposure changed from simulated gastric to simulated intestinal juice, supporting their protective and enzyme-responsive properties [83]. Van Hove et al. developed an enzymatically-responsive PEG hydrogel containing pro-angiogenic peptides that demonstrated significant release in the presence of MMP2 as either cancer treatment or to reduce inflammation [84]. Peptide cleaving occurred at desired sites with no non-specific degradation transpiring when released from hydrogels [84]. Lee et al. investigated how to stabilize insulin at elevated temperatures by developing a novel trehalose-based hydrogel with the glucose-triggered release of insulin [85]. Data showed that the glucose-responsive trehalose hydrogel is effective against heating stress, retaining more than $50 \%$ of the loaded cargo at elevated temperatures [85]. The trehalose glycopolymers are active stabilizers for proteins, including insulin [86-90].

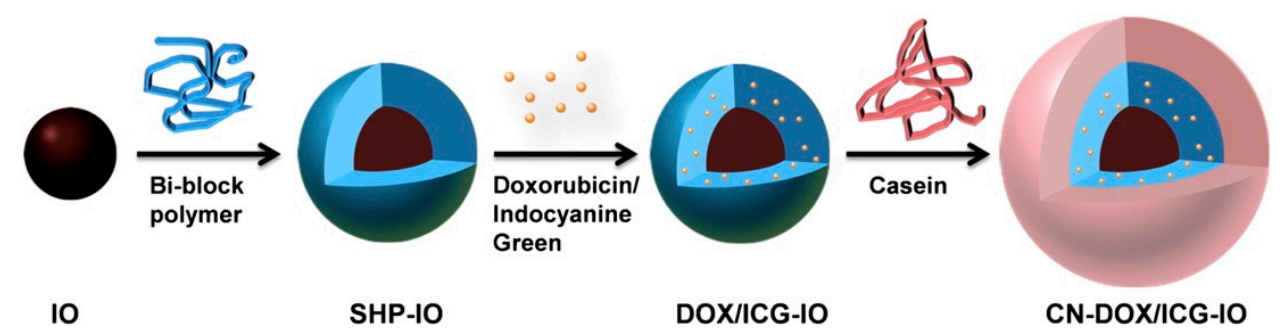

Figure 6. Illustration of layer-by-layer assembled casein coated iron oxide nanoparticles loaded with drug (DOX/Indocyanine green). Reprinted with permission from Biomaterials, 2015, 39, 105-113. Copyright (2015) Elsevier Ltd.

Enzyme-responsive systems have multiple applications across a myriad of diseases or ailments. An advantage of enzyme-responsive systems is the selectivity and built-in internally-stimulated mechanism, taking advantage of the pathological or physiological microenvironment, thereby reducing the potential for toxicity in healthy cells and tissues. Disadvantages include the release of the drug before reaching the intended target. For this reason, enzyme-responsive biomaterials possess other stimuli-responsive properties, i.e., $\mathrm{pH}$, to protect the cargo until reaching the destination. Additionally, exposure of the biomaterial to its enzyme trigger or a closely related enzyme could release the load prematurely.

\section{Multi Stimuli-Responsive Systems}

The integration of multiple stimuli offers the opportunity to increase the fine-tuning of responses for each stimulus with the possibility of regulating the release profile. Multi-responsive systems provide the ability to preserve the primary drug until the intended target is reached. Recent studies have explored carriers to enhance drug delivery and simultaneously offer additional modes of treatment. Multi-response systems are addressing previous issues, such as low drug loading capacities, undesired drug release while in circulation, and any potential non-biodegradable properties, among many. Improving the goals of noninvasiveness and pinpointing intracellular release are some benefits of recent investigations. There remains a plethora of work to be done when it comes to meeting the challenges that any stimuli-responsive system faces but combining as many stimuli as needed offers solutions that were once not seen as possible.

Gold nanocages are investigated for therapeutic applications due to their porous walls, hollow interiors, and tunable localized plasma resonance peaks (LSPRs) that reside in the NIR region [91,92]. 
Wang et al. designed a multi-stimuli responsive nanosystem based on drug-loaded gold nanocages with hyaluronic acid with pinpointed intracellular drug release in conjunction with the synergistic combination of chemotherapy and phototherapy [73]. When no hyaluronidase was present, the release of encapsulated DOX was negligible in contrast to a significant burst release when exposed to hyaluronidase, with the addition of NIR irradiation increasing release [73]. A PEGylated multi-responsive copolymer-DOX prodrug model system was investigated for the delivery of hydrophobic drugs [93]. The presence or absence of GSH and Cathepsin B does not influence the release amount of DOX in more acidic conditions but increases the release rate when present, whereas at physiological pH, the enzymes have no effect [93]. To deliver drugs to breast and cervical cancer, Kashyap et al. designed a thermal and enzymatically responsive amphiphilic copolymer to release DOX, finding that polymers released $90 \%$ of the loaded DOX when temperatures were similar to cancerous tissues compared to only $20 \%$ at average physiological temperatures [94]. Similarly, these DOX-loaded polymers released $90 \%$ of the loaded drug within $12 \mathrm{~h}$ in the presence of esterase, and $20 \%$ in the absence [94].

Hervault et al. investigated a controlled drug delivery system with $\mathrm{pH}$ - and thermo-responsiveness for multi-modal cancer therapy through the combination of magnetic targeting and hyperthermia, through the formation of $\mathrm{pH}$-sensitive imine bonds between the amine group of DOX and the polymer's aldehyde group [95]. The maximal release of DOX occurred at a $\mathrm{pH}$ of 5.7 and $50{ }^{\circ} \mathrm{C}$ when exposed to both stimuli, concurrently [95]. Li et al. composed dual-responsive hybrid mats with ketoprofen (KET), poly(N-vinylcaprolactam), ethyl cellulose, and Eudragit L100 in various combinations as a drug delivery system that demonstrated a $\mathrm{pH}$-dependence independent of temperature, with higher responses in less acidic environments [96]. KET released from the mats when exposed to dual stimuli emulated the results achieved when singularly stimulated, with the most significant and rapid release occurring at $\mathrm{pH} 7.4$ and $25^{\circ} \mathrm{C}$ [96].

Daravan et al. investigated a thermal- and $\mathrm{pH}$-responsive $\mathrm{ABC}$ triblock copolymer for enhancing the delivery of DOX, which demonstrated a faster release in acidic conditions, with release decreasing as a function of increasing $\mathrm{pH}$ at the average body temperature [97]. When the temperature rose to $46^{\circ} \mathrm{C}$, the release rates for all $\mathrm{pH}$ values decreased [97]. For on-demand activation after light excitation, de Solorzano et al. synthesized a novel amine-terminated $\mathrm{P}\left(\mathrm{MEO}_{2} \mathrm{MA}-\mathrm{co}-\mathrm{OEGMA}\right)$ surface-grafted to plasmonic copper sulfide nanoparticles, which produced a cleavable thermo-responsive nanocomposite, to host and release bupivacaine anesthetic [98]. As the temperature increased from 37 to $45^{\circ} \mathrm{C}$, drug release occurred at higher rates, with even higher release achieved when composites were stepwise irradiated with an $808 \mathrm{~nm}$ laser $\left(1.89 \mathrm{~W} \mathrm{~cm}^{-2}\right)$ [98]. Photothermal-chemotherapy (PT-CT) has promise, but due to issues related to the safety of carriers and drug release profiles, this led to a system consisting of PEG-modified polydopamine nanoparticles (PDA-PEG) loaded with DOX to treat cancer with NIR-, $\mathrm{pH}-$, and redox-stimuli capability [99]. DOX release from PDA-PEG, when exposed to NIR irradiation, increased as a function of time and in acidic conditions [99].

Multi-responsive systems allow researchers to fine-tune systems to meet current challenges that may have been more difficult to overcome. Protection of the cargo is a primary advantage that multi-responsive systems possess over their mono-responsive counterparts. Recent investigations have increased modes of layered stimuli to at times three or more, offering higher chances for success. The complexity of these systems and their fabrication can be a limiting factor as investigators seek clinical translation. 
Table 1. Summary of featured stimuli-responsive polymers.

\begin{tabular}{|c|c|c|c|}
\hline Stimuli & Polymer & Major Result(s) & Ref(s) \\
\hline $\mathrm{pH}$ & $\begin{array}{c}\text { N-carboxyethyl } \\
\text { chitosan/dibezaldehyde- terminated } \\
\text { poly(ethylene glycol) }\end{array}$ & $\begin{array}{l}\mathrm{pH} \text { changes promote chemical and } \\
\text { physical modifications that swell the } \\
\text { system inducing cargo release }\end{array}$ & Qu et al. [6] \\
\hline $\mathrm{pH}$ & Poly(lactic acid)-poly(ethyleneimine) & $\begin{array}{l}\text { Burst release of doxorubicin (DOX) } \\
\text { as pH shifted from } 7.4 \text { to } 5.4\end{array}$ & Li et al. [2] \\
\hline $\mathrm{pH}$ & Poly(lactic-co-glycolic acid) (PLGA) & $\begin{array}{l}\text { Morphological change induces drug } \\
\text { release }\end{array}$ & Chung et al. [11] \\
\hline $\mathrm{pH}$ & Poly(acrylamide) & Drug release at $\mathrm{pH}>4.0$ & Pafiti et al. [18] \\
\hline Ultrasound & Poly(ethylene glycol) & $\begin{array}{l}\text { Led to a six-fold increase in the } \\
\text { cumulative release }\end{array}$ & Kearney et al. [19] \\
\hline Ultrasound & Alginate & $\begin{array}{l}\text { Pulsed stimulation outperformed } \\
\text { constant stimulation }\end{array}$ & Huebsch et al. [20] \\
\hline Ultrasound & Chitosan & $\begin{array}{c}\text { Significant release compared to no } \\
\text { stimulus }\end{array}$ & Zhou et al. [21] \\
\hline Ultrasound & Poly(methacrylic acid) (PMAA) & $\begin{array}{l}\text { Design a three in one theranostic } \\
\text { nanoplatform for imaging and } \\
\text { release }\end{array}$ & Yang et al. [22] \\
\hline Ultrasound & Poly(2-oxazoline) micelles & $\begin{array}{l}\text { Possible carrier with increased } \\
\text { release }\end{array}$ & Salgarella et al. [25] \\
\hline Ultrasound & polylactic acid (PLA) & $\begin{array}{l}\text { Long-term encapsulation of small } \\
\text { hydrophilic molecules and four } \\
\text { times the release profile with HIFU }\end{array}$ & Gai et al. [26] \\
\hline UV & $\begin{array}{l}\text { Spiropyran-hyperbranched } \\
\text { polyglycerol micelle }\end{array}$ & $\begin{array}{l}\text { Assembly and disassembly of } \\
\text { micelle induced by UV light } \\
\text { exposure controls the drug release. } \\
\text { Superior biocompatibility with cells } \\
\text { in the absence of UV }\end{array}$ & Son et al. [34] \\
\hline UV & Azobenzene- $\beta$-galactose micelle & $\begin{array}{l}\text { Short UV exposure }(2 \mathrm{~min}) \text { to } \\
\text { release drug; low cytotoxicity of } \\
\text { unloaded micelles }\end{array}$ & Pearson et al. [36] \\
\hline UV & $\begin{array}{l}\text { 2-hydroxyethyl methacrylate and } \\
\text { ethylene glycol dimethacrylate }\end{array}$ & $\begin{array}{l}\text { Deliver multiple doses of drug upon } \\
\text { UV exposure over a prolonged } \\
\text { period of time }(\leq 160 \mathrm{~h})\end{array}$ & Hardy et al. [37] \\
\hline UV & mPEG-PLGA nanoparticle & $\begin{array}{l}\text { Reverse multidrug resistance of } \\
\text { tumor cells; enhance } \\
\text { chemosensitization of cells to DOX } \\
\text { therapy }\end{array}$ & Fan et al. [38] \\
\hline NIR & $\begin{array}{l}\text { Diselenide-cross-linked } \\
\text { poly(methacrylic acid) }\end{array}$ & $\begin{array}{l}\text { Controlled illumination with } \\
\text { specific number of irradiation times } \\
\text { allowed for on-demand controlled } \\
\text { drug release and nanogel } \\
\text { degradation. Rapid internalization } \\
\text { by HeLa cell and cytotoxic under } \\
\text { NIR irradiation }\end{array}$ & Tian et al. [40] \\
\hline NIR & B-cylcodextrin & $\begin{array}{l}\text { Anticancer activity in vitro and } \\
\text { in vivo against breast cancer, with } \\
\text { accelerated drug release upon NIR } \\
\text { exposure }\end{array}$ & Liang et al. [41] \\
\hline NIR & Polycaprolactone & $\begin{array}{l}\text { On-demand, stepwise drug-release } \\
\text { after multiple cycles of NIR } \\
\text { exposure with low off-state leakage. }\end{array}$ & Chen et al. [42] \\
\hline Red light & $\begin{array}{l}\text { Tetra-ortho-methoxy- substituted } \\
\text { azobenzene \& } \beta \text {-cyclodextrin }\end{array}$ & $\begin{array}{l}\text { Responsive to red light instead of } \\
\text { UV. Deeper tissue penetration depth }\end{array}$ & Wang et al. [44] \\
\hline
\end{tabular}


Table 1. Cont.

\begin{tabular}{|c|c|c|c|}
\hline Stimuli & Polymer & Major Result(s) & $\operatorname{Ref}(s)$ \\
\hline AMF & Aminosilan-type shell & $\begin{array}{l}\text { EMF stimulation of SPIONS can } \\
\text { maintain elevated temperatures of } \\
\text { approximately } 45^{\circ} \mathrm{C} \text { in } \\
\text { glioblastoma multiforme tumors }\end{array}$ & $\begin{array}{l}\text { Maier-Hauff et al. } \\
\text { [47] }\end{array}$ \\
\hline AMF & Polyethylene glycol w/azo drug linker & $\begin{array}{l}\text { SPION local temperature can } \\
\text { increase up to } 50^{\circ} \mathrm{C} \text { without } \\
\text { inducing significant temperature } \\
\text { increases in media at sufficiently } \\
\text { low concentrations }\end{array}$ & Riedinger et al. [48] \\
\hline AMF & $\begin{array}{c}\text { (N-isopropylacrylamide)- } \\
\text { (N-hydroxymethyl) acrylamide }\end{array}$ & $\begin{array}{l}\text { SPION stimulation can trigger } \\
\text { PNIPAM critical temperature } \\
\text { transition without increasing } \\
\text { temperature of surrounding media }\end{array}$ & Guisasola et al. [49] \\
\hline AMF & $\begin{array}{c}\text { Poly(maleic } \\
\text { anhydride-alt-1-octadecene) }\end{array}$ & $\begin{array}{l}\text { Distance from the nanoparticle } \\
\text { surface can be used to control } \\
\text { temperature dependent effects } \\
\text { during AMF stimulation }\end{array}$ & Dias et al. [50] \\
\hline AMF & PLGA & $\begin{array}{l}\text { SPION stimulation induced drug } \\
\text { release by increasing temperature } \\
\text { above the glass transition of PLGA }\end{array}$ & $\begin{array}{l}\text { Thirunavukkarasu et } \\
\text { al. [51] }\end{array}$ \\
\hline $\begin{array}{l}\text { Permanent } \\
\text { magnet }\end{array}$ & Tetramethylazanium hydroxide & $\begin{array}{c}\text { Intrathecally delivered SPIONS } \\
\text { loaded with NSAIDS produced } \\
\text { magnetic field dependent reductions } \\
\text { in pain and inflammatory markers } \\
\text { in a murine model }\end{array}$ & Wu et al. [52] \\
\hline $\begin{array}{l}\text { Permanent } \\
\text { magnet }\end{array}$ & Polyethyleneimine & $\begin{array}{c}\text { External magnetic guidance } \\
\text { improved accumulation of SPIONS } \\
\text { in arthritic joints in a rat model }\end{array}$ & Duan et al. [54] \\
\hline AMF & Chitosan-polyethylene glycol & $\begin{array}{l}\text { SPION loaded microbeads can } \\
\text { respond to multiple stimuli and } \\
\text { increase drug release to efficacious } \\
\text { levels as the carrier nears exhaustion }\end{array}$ & Mohapatra et al. [56] \\
\hline Electric & Agarose/alginate-aniline tetramer & $\begin{array}{l}\text { Conductive tetramers improve } \\
\text { hydrogel biocompatability with } \\
\text { neural cells and enables repeat } \\
\text { stimuli responsive drug release }\end{array}$ & Atoufi et al. [59] \\
\hline Electric & Poly(3,4-ethylenedioxypyrrole) & $\begin{array}{l}\text { Stimulation induces rapid release of } \\
\text { ionically bound ibuprofen but not } \\
\text { ibuprofen physically entrapped in } \\
\text { the matrix during electrochemical } \\
\text { polymerization }\end{array}$ & Krukiewicz et al. [60] \\
\hline Electric & $\begin{array}{l}\text { Poly(3-methoxydiphenylamine)/Pectin } \\
\text { blend }\end{array}$ & $\begin{array}{l}\text { Stimulation increased hydrogel } \\
\text { mesh pore size allowing increased } \\
\text { drug elution }\end{array}$ & $\begin{array}{l}\text { Mongkolkitikul et al. } \\
\text { [61] }\end{array}$ \\
\hline Electric & Polypyrrole & $\begin{array}{l}\text { Sacrificial templates can be used to } \\
\text { create electrically responsive } \\
\text { nanowires }\end{array}$ & Lee et al. [62] \\
\hline Electric & $\begin{array}{l}\text { Monoferrocene functionalized } \\
\beta \text {-cyclodextrin }\end{array}$ & $\begin{array}{l}\text { Stimulus-induced conformational } \\
\text { changes can be used to control } \\
\text { polymeric 'gates' for on/off delivery } \\
\text { using mesoporous particles }\end{array}$ & Wang et al. [63] \\
\hline Enzyme & $\begin{array}{c}\text { PEGylated alkynylated peptide } \\
\text { dendrimer }\end{array}$ & $\begin{array}{l}\text { Minimal release in the absence of } \\
\text { Cathepsin B }\end{array}$ & Zhang et al. [75] \\
\hline
\end{tabular}


Table 1. Cont

\begin{tabular}{|c|c|c|c|}
\hline Stimuli & Polymer & Major Result(s) & $\operatorname{Ref}(s)$ \\
\hline Enzyme & $\begin{array}{l}\text { Polydimethylsiloxane, } \\
\text { polyethylenimine }\end{array}$ & $\begin{array}{l}\text { Release in the presence of HAS, E. } \\
\text { coli, or } S \text {. aureus }\end{array}$ & Wang et al. [82] \\
\hline Enzyme & Poly(maleic acid) & $\begin{array}{l}\text { No release until exposure to } \\
\text { intestine protease trypsin }\end{array}$ & Huang et al. [83] \\
\hline Enzyme & Poly(ethylene glycol) & Peptide cleaving at desired sites & Van Hove et al. [84] \\
\hline Enzyme & $\begin{array}{l}\text { Poly(styrenyl ether trehalose), } \\
\text { poly(ethylene glycol) }\end{array}$ & $\begin{array}{l}\text { Ability to withstand elevated } \\
\text { temperatures with cargo intact }\end{array}$ & Lee et al. [85] \\
\hline Enzyme, NIR & Poly(vinyl pyrrolidone) & $\begin{array}{l}\text { Minimal release in the absence of } \\
\text { hyaluronidase, NIR promoting } \\
\text { more release }\end{array}$ & Wang et al. [73] \\
\hline Enzyme, pH & Poly(ethylene glycol) & $\begin{array}{l}\text { Release rate increase at pH } 5.4 \text { in } \\
\text { presence of cathepsin B and } \\
\text { glutathione }\end{array}$ & Duan et al. [93] \\
\hline $\begin{array}{l}\text { Enzyme, } \\
\text { Thermal }\end{array}$ & $\begin{array}{l}\text { 3-pentadecylphenol, oligoethylene } \\
\text { glycol acrylate }\end{array}$ & $\begin{array}{c}\text { Proposed release at tissue based on } \\
\text { temperature with intracellular } \\
\text { release concurrent with enzyme } \\
\text { exposure }\end{array}$ & Kashyap et al. [94] \\
\hline $\mathrm{pH}$, Thermal & $\begin{array}{l}\text { Poly(ethylene glycol) methyl ether } \\
\text { methacrylate }\end{array}$ & $\begin{array}{l}\mathrm{pH} \text { and temperature greatly } \\
\text { influence the release of DOX }\end{array}$ & Hervault et al. [95] \\
\hline $\mathrm{pH}$, Thermal & $\begin{array}{l}\text { Poly(N-vinylcaprolactam), ethyl } \\
\text { cellulose, Eudagrit L100 }\end{array}$ & $\begin{array}{l}\text { Most pronounced release occurred } \\
\text { at } 25^{\circ} \mathrm{C} \text { and pH } 7.4\end{array}$ & Li et al. [96] \\
\hline $\mathrm{pH}$, Thermal & $\begin{array}{c}\text { Poly(2-succinyloxyethyl } \\
\text { methacrylate)- } b \text {-(N-isopropylacrylamide)- } \\
b-[(N-4 \text {-vinylbenzyl),N,N-diethylamine }], \\
[\text { P(SEMA- } b \text {-NIPAAm- } b \text {-VEA })]\end{array}$ & $\begin{array}{c}\text { Greatest DOX release observed at } \\
37^{\circ} \mathrm{C} \text { and } \mathrm{pH} 4 \text {, increase in } \\
\text { temperature led to decrease in DOX } \\
\text { release }\end{array}$ & Davaran et al. [97] \\
\hline NIR, Thermal & $\begin{array}{l}\text { Poly(ethylene glycol) methyl ether } \\
\text { methacrylate, poly(vinyl pyrrolidone) }\end{array}$ & $\begin{array}{l}\text { Release was higher at } 45^{\circ} \mathrm{C} \text { with a } \\
\text { burst increase synonymous with } \\
\text { NIR irradiation }\end{array}$ & $\begin{array}{l}\text { Ortiz de Solorzano et } \\
\text { al. [98] }\end{array}$ \\
\hline $\begin{array}{l}\text { NIR, } \mathrm{pH} \\
\text { Redox }\end{array}$ & Poly(ethylene glycol), poly(dopamine) & $\begin{array}{l}\text { NIR irradiation release is function of } \\
\text { exposure time, } \mathrm{pH} \text { and redox release } \\
\text { greatest at } \mathrm{pH} 7.4\end{array}$ & Wang et al. [99] \\
\hline
\end{tabular}

\section{Conclusions}

Stimuli-responsive systems have evolved to respond to various modes of internal- and external-stimuli, or both. These advances present researchers and clinicians with great promise in enhancing current treatment options as well as future solutions. Over the past decade, stimuli-responsive systems have expanded the horizon of smart biomaterials while improving precision to improve the efficacy and reduce off-target toxicity of therapeutic molecules. Chemical, physical, and biological stimuli may be internal or externally triggered to boost or trigger drug release in particular tissue or disease states. While several recent works have advanced the field, primary limitations for each of these types of smart polymer biomaterials rests on the ability to penetrate deeper layers of tissue and limiting unintended tissue damage for physical-based triggers. Ongoing efforts to keep the payload retained until desired stimulation is a recurring limiting factor that requires future progress. While results in vitro and from preclinical studies provide promising evidence, few polymeric smart biomaterials have advanced to clinical studies of efficacy and safety. Clinical evaluations of safety are needed to improve the future of smart drug delivery vehicles.

Author Contributions: Conceptualization, C.M.W. and J.A.J.; Planning, C.M.W. and J.A.J.; Literature Review, C.M.W., J.A.J., and M.H.; Writing-Original Draft Preparation, C.M.W., M.H., L.C., V.P.M., F.D.G., and J.A.J.; Writing-Review, C.M.W., M.H., V.P.M., and F.D.G; Writing-Review \& Editing, C.M.W. and J.A.J.

Funding: Carlos M. Wells was supported by a Tennessee Doctoral Research Fellowship. Michael Harris was supported by a National Science Foundation Graduate Research Fellowship. Landon Choi and J. Amber Jennings were supported by National Institute of Arthritis and Musculoskeletal and Skin Disease of the National Institutes of Health (NIH) under Award Number R01AR066050. Fernanda Delbuque Guerra and Vishnu Murali were 
supported by the National Institute of Dental and Craniofacial Research of the National Institutes of Health R01DE026759. The content of this manuscript is solely the responsibility of the authors and does not necessarily represent the official views of the NIH.

Acknowledgments: Authors would like to thank the Herff College of Engineering, the Department of Biomedical Engineering at The University of Memphis, Hope Clippinger, Lakesha Herring, Regina Hairston, Joel D. Bumgardner, and the Southern Regional Education Board.

Conflicts of Interest: The authors declare no conflict of interest.

\section{References}

1. Ganta, S.; Devalapally, H.; Shahiwala, A.; Amiji, M. A review of stimuli-responsive nanocarriers for drug and gene delivery. J. Contr. Release 2008, 126, 187-204. [CrossRef] [PubMed]

2. Li, S.; Hu, K.; Cao, W.; Sun, Y.; Sheng, W.; Li, F.; Wu, Y.; Liang, X.J. Ph-responsive biocompatible fluorescent polymer nanoparticles based on phenylboronic acid for intracellular imaging and drug delivery. Nanoscale 2014, 6, 13701-13709. [CrossRef] [PubMed]

3. Zhao, Y.; Guo, Y.; Tang, L. Engineering cancer vaccines using stimuli-responsive biomaterials. Nano Res. 2018, 11, 5355-5371. [CrossRef]

4. Wei, M.; Gao, Y.; Li, X.; Serpe, M.J. Stimuli-responsive polymers and their applications. Polym. Chem. 2017, 8, 127-143. [CrossRef]

5. Jing, L.; Liang, X.; Li, X.; Yang, Y.; Dai, Z. Covalent attachment of Mn-porphyrin onto doxorubicin-loaded poly (lactic acid) nanoparticles for potential magnetic resonance imaging and $\mathrm{pH}$-sensitive drug delivery. Acta Biomater. 2013, 9, 9434-9441. [CrossRef] [PubMed]

6. Qu, J.; Zhao, X.; Ma, P.X.; Guo, B. pH-responsive self-healing injectable hydrogel based on N-carboxyethyl chitosan for hepatocellular carcinoma therapy. Acta Biomater. 2017, 58, 168-180. [CrossRef] [PubMed]

7. Shi, S.; Liu, Y.; Chen, Y.; Zhang, Z.; Ding, Y.; Wu, Z.; Yin, J.; Nie, L. Versatile pH-response micelles with high cell-penetrating helical diblock copolymers for photoacoustic imaging guided synergistic chemo-photothermal therapy. Theranostics 2016, 6, 2170. [CrossRef] [PubMed]

8. Tekade, R.K.; Tekade, M.; Kumar, M.; Chauhan, A.S. Dendrimer-stabilized smart-nanoparticle (DSSN) platform for targeted delivery of hydrophobic antitumor therapeutics. Pharm. Res. 2015, 32, 910-928. [CrossRef] [PubMed]

9. Unsoy, G.; Yalcin, S.; Khodadust, R.; Mutlu, P.; Onguru, O.; Gunduz, U. Chitosan magnetic nanoparticles for $\mathrm{pH}$ responsive Bortezomib release in cancer therapy. Biomed. Pharmacother. 2014, 68, 641-648.

10. Aycan, D.; Alemdar, N. Development of $\mathrm{pH}$-responsive chitosan-based hydrogel modified with bone ash for controlled release of amoxicillin. Carbohydr. Polym. 2018, 184, 401-407. [CrossRef]

11. Chung, M.F.; Chia, W.T.; Liu, H.Y.; Hsiao, C.W.; Hsiao, H.C.; Yang, C.M.; Sung, H.W. Inflammation-Induced Drug Release by using a pH-Responsive Gas-Generating Hollow-Microsphere System for the Treatment of Osteomyelitis. Adv. Healthc. Mater. 2014, 3, 1854-1861. [CrossRef]

12. Li, X.; Fu, M.; Wu, J.; Zhang, C.; Deng, X.; Dhinakar, A.; Huang, W.; Qian, H.; Ge, L. pH-sensitive peptide hydrogel for glucose-responsive insulin delivery. Acta Biomater. 2017, 51, 294-303. [CrossRef] [PubMed]

13. Shah, P.V.; Rajput, S.J. Facile synthesis of chitosan capped mesoporous silica nanoparticles: A pH responsive smart delivery platform for raloxifene hydrochloride. AAPS PharmSciTech 2018, 19, 1344-1357. [CrossRef] [PubMed]

14. Zhao, G.; Wang, J.; Peng, X.; Li, Y.; Yuan, X.; Ma, Y. Facile Solvothermal synthesis of mesostructured $\mathrm{Fe}_{3} \mathrm{O}_{4} /$ chitosan nanoparticles as delivery vehicles for $\mathrm{pH}$-responsive drug delivery and magnetic resonance imaging contrast agents. Chem. Asian J. 2014, 9, 546-553. [CrossRef] [PubMed]

15. Majumdar, S.; Krishnatreya, G.; Gogoi, N.; Thakur, D.; Chowdhury, D. Carbon-dot-coated alginate beads as a smart stimuli-responsive drug delivery system. ACS Appl. Mater. Interfaces 2016, 8, 34179-34184. [CrossRef] [PubMed]

16. Ouyang, L.; Sun, Z.; Wang, D.; Qiao, Y.; Zhu, H.; Ma, X.; Liu, X. Smart release of doxorubicin loaded on polyetheretherketone (PEEK) surface with 3D porous structure. Colloids Surf. B Biointerfaces 2018, 163, 175-183. [CrossRef]

17. Kocak, G.; Tuncer, C.; Butun, V. Ph-responsive polymers. Polym. Chem. 2017, 8, 144-176. [CrossRef] 
18. Pafiti, K.; Cui, Z.; Adlam, D.; Hoyland, J.; Freemont, A.J.; Saunders, B.R. Hydrogel composites containing sacrificial collapsed hollow particles as dual action pH-responsive biomaterials. Biomacromolecules 2016, 17, 2448-2458. [CrossRef] [PubMed]

19. Kearney, C.J.; Skaat, H.; Kennedy, S.M.; Hu, J.; Darnell, M.; Raimondo, T.M.; Mooney, D.J. Switchable release of entrapped nanoparticles from alginate hydrogels. Adv. Healthc. Mater. 2015, 4, 1634-1639. [CrossRef] [PubMed]

20. Huebsch, N.; Kearney, C.J.; Zhao, X.; Kim, J.; Cezar, C.A.; Suo, Z.; Mooney, D.J. Ultrasound-triggered disruption and self-healing of reversibly cross-linked hydrogels for drug delivery and enhanced chemotherapy. Proc. Natl. Acad. Sci. USA 2014, 111, 9762-9767. [CrossRef] [PubMed]

21. Zhou, X.; Guo, L.; Shi, D.; Duan, S.; Li, J. Biocompatible Chitosan Nanobubbles for Ultrasound-Mediated Targeted Delivery of Doxorubicin. Nanoscale Res. Lett. 2019, 14, 24. [CrossRef] [PubMed]

22. Yang, P.; Li, D.; Jin, S.; Ding, J.; Guo, J.; Shi, W.; Wang, C. Stimuli-responsive biodegradable poly (methacrylic acid) based nanocapsules for ultrasound traced and triggered drug delivery system. Biomaterials 2014, 35, 2079-2088. [CrossRef] [PubMed]

23. Nguyen, K.; Pan, H.Y.; Haworth, K.; Mahoney, E.; Mercado-Shekhar, K.P.; Lin, C.Y.; Zhang, Z.; Park, Y.C. Multiple-exposure drug release from stable nanodroplets by high-intensity focused ultrasound for a potential degenerative disc disease treatment. Ultrasound Med. Biol. 2018, 45, 160-169. [CrossRef] [PubMed]

24. Cao, Y.; Chen, Y.; Yu, T.; Guo, Y.; Liu, F.; Yao, Y.; Li, P.; Wang, D.; Wang, Z.; Chen, Y. Drug release from phase-changeable nanodroplets triggered by low-intensity focused ultrasound. Theranostics 2018, 8, 1327. [CrossRef] [PubMed]

25. Salgarella, A.R.; Zahoranová, A.; Šrámková, P.; Majerčíková, M.; Pavlova, E.; Luxenhofer, R.; Kronek, J.; Lacík, I.; Ricotti, L. Investigation of drug release modulation from poly (2-oxazoline) micelles through ultrasound. Sci. Rep. 2018, 8, 9893. [CrossRef]

26. Gai, M.; Frueh, J.; Tao, T.; Petrov, A.V.; Petrov, V.V.; Shesterikov, E.V.; Tverdokhlebov, S.I.; Sukhorukov, G.B. Polylactic acid nano-and microchamber arrays for encapsulation of small hydrophilic molecules featuring drug release via high intensity focused ultrasound. Nanoscale 2017, 9, 7063-7070. [CrossRef]

27. Park, W.; Bae, B.-c.; Na, K. A highly tumor-specific light-triggerable drug carrier responds to hypoxic tumor conditions for effective tumor treatment. Biomaterials 2016, 77, 227-234. [CrossRef]

28. Higuchi, A.; Ling, Q.-D.; Kumar, S.S.; Chang, Y.; Kao, T.-C.; Munusamy, M.A.; Alarfaj, A.A.; Hsu, S.-T.; Umezawa, A. External stimulus-responsive biomaterials designed for the culture and differentiation of ES, iPS, and adult stem cells. Prog. Polym. Sci. 2014, 39, 1585-1613. [CrossRef]

29. Alonso-Cristobal, P.; Oton-Fernandez, O.; Mendez-Gonzalez, D.; Díaz, J.F.; Lopez-Cabarcos, E.; Barasoain, I.; Rubio-Retama, J. Synthesis, characterization, and application in HeLa cells of an NIR light responsive doxorubicin delivery system based on NaYF4: Yb, Tm@ SiO2-PEG nanoparticles. ACS Appl. Mater. Interface 2015, 7, 14992-14999.

30. Shell, T.A.; Lawrence, D.S. Vitamin B12: A tunable, long wavelength, light-responsive platform for launching therapeutic agents. Acc. Chem. Res. 2015, 48, 2866-2874. [CrossRef]

31. Yang, G.; Liu, J.; Wu, Y.; Feng, L.; Liu, Z. Near-infrared-light responsive nanoscale drug delivery systems for cancer treatment. Coord. Chem. Rev. 2016, 320, 100-117. [CrossRef]

32. Bunker, B.; Kim, B.; Houston, J.; Rosario, R.; Garcia, A.; Hayes, M.; Gust, D.; Picraux, S. Direct observation of photo switching in tethered spiropyrans using the interfacial force microscope. Nano Lett. 2003, 3, 1723-1727. [CrossRef]

33. Higuchi, A.; Hamamura, A.; Shindo, Y.; Kitamura, H.; Yoon, B.O.; Mori, T.; Uyama, T.; Umezawa, A. Photon-modulated changes of cell attachments on poly (spiropyran-co-methyl methacrylate) membranes. Biomacromolecules 2004, 5, 1770-1774. [CrossRef] [PubMed]

34. Son, S.; Shin, E.; Kim, B.-S. Light-responsive micelles of spiropyran initiated hyperbranched polyglycerol for smart drug delivery. Biomacromolecules 2014, 15, 628-634. [CrossRef] [PubMed]

35. Liu, D.; Xie, Y.; Shao, H.; Jiang, X. Using azobenzene-embedded self-assembled monolayers to photochemically control cell adhesion reversibly. Angew. Chem. Int. Ed. 2009, 48, 4406-4408. [CrossRef] [PubMed]

36. Pearson, S.; Vitucci, D.; Khine, Y.Y.; Dag, A.; Lu, H.; Save, M.; Billon, L.; Stenzel, M.H. Light-responsive azobenzene-based glycopolymer micelles for targeted drug delivery to melanoma cells. Eur. Polym. J. 2015, 69, 616-627. [CrossRef] 
37. Hardy, J.G.; Larrañeta, E.; Donnelly, R.F.; McGoldrick, N.; Migalska, K.; McCrudden, M.T.; Irwin, N.J.; Donnelly, L.; McCoy, C.P. Hydrogel-forming microneedle arrays made from light-responsive materials for on-demand transdermal drug delivery. Mol. Pharm. 2016, 13, 907-914. [CrossRef] [PubMed]

38. Fan, J.; He, Q.; Liu, Y.; Zhang, F.; Yang, X.; Wang, Z.; Lu, N.; Fan, W.; Lin, L.; Niu, G. Light-responsive biodegradable nanomedicine overcomes multidrug resistance via no-enhanced chemosensitization. ACS Appl. Mater. Interfaces 2016, 8, 13804-13811. [CrossRef]

39. Poelma, S.O.; Oh, S.S.; Helmy, S.; Knight, A.S.; Burnett, G.L.; Soh, H.T.; Hawker, C.J.; de Alaniz, J.R. Controlled drug release to cancer cells from modular one-photon visible light-responsive micellar system. Chem. Commun. 2016, 52, 10525-10528. [CrossRef]

40. Tian, Y.; Zheng, J.; Tang, X.; Ren, Q.; Wang, Y.; Yang, W. Near-infrared light-responsive nanogels with diselenide-cross-linkers for on-demand degradation and triggered drug release. Part. Part. Syst. Charact. 2015, 32, 547-551. [CrossRef]

41. Liang, Y.; Gao, W.; Peng, X.; Deng, X.; Sun, C.; Wu, H.; He, B. Near infrared light responsive hybrid nanoparticles for synergistic therapy. Biomaterials 2016, 100, 76-90. [CrossRef] [PubMed]

42. Chen, M.C.; Ling, M.H.; Wang, K.W.; Lin, Z.W.; Lai, B.H.; Chen, D.H. Near-infrared light-responsive composite microneedles for on-demand transdermal drug delivery. Biomacromolecules 2015, 16, 1598-1607. [CrossRef] [PubMed]

43. Wang, D.; Wu, S. Red-light-responsive supramolecular valves for photocontrolled drug release from mesoporous nanoparticles. Langmuir 2016, 32, 632-636. [CrossRef] [PubMed]

44. Wang, D.; Wagner, M.; Butt, H.J.; Wu, S. Supramolecular hydrogels constructed by red-light-responsive host-guest interactions for photo-controlled protein release in deep tissue. Soft Matter 2015, 11, 7656-7662. [CrossRef] [PubMed]

45. Laurent, S.; Dutz, S.; Häfeli, U.O.; Mahmoudi, M. Magnetic fluid hyperthermia: Focus on superparamagnetic iron oxide nanoparticles. Adv. Colloid Interface Sci. 2011, 166, 8-23. [CrossRef] [PubMed]

46. Johannsen, M.; Gneveckow, U.; Eckelt, L.; Feussner, A.; Waldöfner, N.; Scholz, R.; Deger, S.; Wust, P.; Loening, S.; Jordan, A. Clinical hyperthermia of prostate cancer using magnetic nanoparticles: Presentation of a new interstitial technique. Int. J. Hyperth. 2005, 21, 637-647. [CrossRef]

47. Maier-Hauff, K.; Rothe, R.; Scholz, R.; Gneveckow, U.; Wust, P.; Thiesen, B.; Feussner, A.; von Deimling, A.; Waldoefner, N.; Felix, R. Intracranial thermotherapy using magnetic nanoparticles combined with external beam radiotherapy: Results of a feasibility study on patients with glioblastoma multiforme. J. Neurooncol. 2007, 81, 53-60. [CrossRef] [PubMed]

48. Riedinger, A.; Guardia, P.; Curcio, A.; Garcia, M.A.; Cingolani, R.; Manna, L.; Pellegrino, T. Subnanometer local temperature probing and remotely controlled drug release based on azo-functionalized iron oxide nanoparticles. Nano Lett. 2013, 13, 2399-2406. [CrossRef] [PubMed]

49. Guisasola, E.; Baeza, A.; Talelli, M.; Arcos, D.; Moros, M.; de la Fuente, J.s.M.; Vallet-Regí, M. Magnetic-responsive release controlled by hot spot effect. Langmuir 2015, 31, 12777-12782. [CrossRef]

50. Dias, J.T.; Moros, M.; del Pino, P.; Rivera, S.; Grazú, V.; de la Fuente, J.M. DNA as a molecular local thermal probe for the analysis of magnetic hyperthermia. Angew. Chem. Int. Ed. 2013, 52, 11526-11529. [CrossRef]

51. Thirunavukkarasu, G.K.; Cherukula, K.; Lee, H.; Jeong, Y.Y.; Park, I.-K.; Lee, J.Y. Magnetic field-inducible drug-eluting nanoparticles for image-guided thermo-chemotherapy. Biomaterials 2018, 180, $240-252$. [CrossRef] [PubMed]

52. Wu, P.C.; Shieh, D.B.; Hsiao, H.T.; Wang, J.C.F.; Lin, Y.C.; Liu, Y.C. Magnetic field distribution modulation of intrathecal delivered ketorolac iron-oxide nanoparticle conjugates produce excellent analgesia for chronic inflammatory pain. J. Nanobiotechnol. 2018, 16, 49. [CrossRef] [PubMed]

53. Dolati, S.; Sadreddini, S.; Rostamzadeh, D.; Ahmadi, M.; Jadidi-Niaragh, F.; Yousefi, M. Utilization of nanoparticle technology in rheumatoid arthritis treatment. Biomed. Pharmacother. 2016, 80, 30-41. [CrossRef] [PubMed]

54. Duan, J.; Dong, J.; Zhang, T.; Su, Z.; Ding, J.; Zhang, Y.; Mao, X. Polyethyleneimine-functionalized iron oxide nanoparticles for systemic siRNA delivery in experimental arthritis. Nanomedicine 2014, 9, 789-801. [CrossRef] [PubMed]

55. Harris, M.; Ahmed, H.; Barr, B.; LeVine, D.; Pace, L.; Mohapatra, A.; Morshed, B.; Bumgardner, J.D.; Jennings, J.A. Magnetic stimuli-responsive chitosan-based drug delivery biocomposite for multiple triggered release. Int. J. Biol. Macromol. 2017, 104, 1407-1414. [CrossRef] [PubMed] 
56. Mohapatra, A.; Harris, M.A.; LeVine, D.; Ghimire, M.; Jennings, J.A.; Morshed, B.I.; Haggard, W.O.; Bumgardner, J.D.; Mishra, S.R.; Fujiwara, T. Magnetic stimulus responsive vancomycin drug delivery system based on chitosan microbeads embedded with magnetic nanoparticles. J. Biomed. Mater. Res. Part B Appl. Biomater. 2018, 106, 2169-2176. [CrossRef]

57. Pillay, V.; Tsai, T.S.; Choonara, Y.E.; du Toit, L.C.; Kumar, P.; Modi, G.; Naidoo, D.; Tomar, L.K.; Tyagi, C.; Ndesendo, V.M. A review of integrating electroactive polymers as responsive systems for specialized drug delivery applications. J. Biomed. Mater. Res. Part A 2014, 102, 2039-2054. [CrossRef]

58. Balint, R.; Cassidy, N.J.; Cartmell, S.H. Conductive polymers: Towards a smart biomaterial for tissue engineering. Acta Biomater. 2014, 10, 2341-2353. [CrossRef]

59. Atoufi, Z.; Zarrintaj, P.; Motlagh, G.H.; Amiri, A.; Bagher, Z.; Kamrava, S.K. A novel bio electro active alginate-aniline tetramer/agarose scaffold for tissue engineering: Synthesis, characterization, drug release and cell culture study. J. Biomater. Sci. Polym. Ed. 2017, 28, 1617-1638. [CrossRef]

60. Krukiewicz, K.; Zawisza, P.; Herman, A.P.; Turczyn, R.; Boncel, S.; Zak, J.K. An electrically controlled drug delivery system based on conducting poly (3, 4-ethylenedioxypyrrole) matrix. Bioelectrochemistry 2016, 108, 13-20. [CrossRef]

61. Mongkolkitikul, S.; Paradee, N.; Sirivat, A. Electrically controlled release of ibuprofen from conductive poly (3-methoxydiphenylamine)/crosslinked pectin hydrogel. Eur. J. Pharm. Sci. 2018, 112, 20-27. [CrossRef] [PubMed]

62. Lee, H.; Hong, W.; Jeon, S.; Choi, Y.; Cho, Y. Electroactive polypyrrole nanowire arrays: Synergistic effect of cancer treatment by on-demand drug release and photothermal therapy. Langmuir 2015, 31, 4264-4269. [CrossRef] [PubMed]

63. Wang, T.; Sun, G.; Wang, M.; Zhou, B.; Fu, J. Voltage/pH-driven mechanized silica nanoparticles for the multimodal controlled release of drugs. ACS Appl. Mater. Interfaces 2015, 7, 21295-21304. [CrossRef] [PubMed]

64. Perrier, D.L.; Rems, L.; Boukany, P.E. Lipid vesicles in pulsed electric fields: Fundamental principles of the membrane response and its biomedical applications. Adv. Colloid Interface Sci. 2017, 249, 248-271. [CrossRef] [PubMed]

65. Bulysheva, A.; Hornef, J.; Edelblute, C.; Jiang, C.; Schoenbach, K.; Lundberg, C.; Malik, M.A.; Heller, R. Coalesced thermal and electrotransfer mediated delivery of plasmid DNA to the skin. Bioelectrochemistry 2019, 125, 127-133. [CrossRef] [PubMed]

66. Ma, S.; Schroeder, B.; Sun, C.; Loufakis, D.N.; Cao, Z.; Sriranganathan, N.; Lu, C. Electroporation-based delivery of cell-penetrating peptide conjugates of peptide nucleic acids for antisense inhibition of intracellular bacteria. Integr. Biol. 2014, 6, 973-978. [CrossRef] [PubMed]

67. Denzi, A.; Della Valle, E.; Apollonio, F.; Breton, M.; Mir, L.M.; Liberti, M. Exploring the applicability of nano-poration for remote control in smart drug delivery systems. Integr. Biol. 2014, 6, 973-978. [CrossRef]

68. van Rijt, S.H.; Bölükbas, D.A.; Argyo, C.; Datz, S.; Lindner, M.; Eickelberg, O.; Königshoff, M.; Bein, T.; Meiners, S. Protease-mediated release of chemotherapeutics from mesoporous silica nanoparticles to ex vivo human and mouse lung tumors. ACS Nano 2015, 9, 2377-2389. [CrossRef]

69. Upreti, M.; Jyoti, A.; Sethi, P. Tumor microenvironment and nanotherapeutics. Transl. Cancer Res. 2013, $2,309$.

70. De La Rica, R.; Aili, D.; Stevens, M.M. Enzyme-responsive nanoparticles for drug release and diagnostics. Adv. Drug Deliv. Rev. 2012, 64, 967-978. [CrossRef]

71. Hu, Q.; Katti, P.S.; Gu, Z. Enzyme-responsive nanomaterials for controlled drug delivery. Nanoscale 2014, 6, 12273-12286. [CrossRef] [PubMed]

72. Qin, S.Y.; Feng, J.; Rong, L.; Jia, H.Z.; Chen, S.; Liu, X.J.; Luo, G.F.; Zhuo, R.X.; Zhang, X.Z. Theranostic GO-Based Nanohybrid for Tumor Induced Imaging and Potential Combinational Tumor Therapy. Small 2014, 10, 599-608. [CrossRef] [PubMed]

73. Wang, Z.; Chen, Z.; Liu, Z.; Shi, P.; Dong, K.; Ju, E.; Ren, J.; Qu, X. A multi-stimuli responsive gold nanocage-hyaluronic platform for targeted photothermal and chemotherapy. Biomaterials 2014, 35, 9678-9688. [CrossRef] [PubMed]

74. Fleige, E.; Quadir, M.A.; Haag, R. Stimuli-responsive polymeric nanocarriers for the controlled transport of active compounds: Concepts and applications. Adv. Drug Deliv. Rev. 2012, 64, 866-884. [CrossRef] [PubMed] 
75. Zhang, C.; Pan, D.; Li, J.; Hu, J.; Bains, A.; Guys, N.; Zhu, H.; Li, X.; Luo, K.; Gong, Q. Enzyme-responsive peptide dendrimer-gemcitabine conjugate as a controlled-release drug delivery vehicle with enhanced antitumor efficacy. Acta Biomater. 2017, 55, 153-162. [CrossRef]

76. Randolph, L.M.; Chien, M.-P.; Gianneschi, N.C. Biological stimuli and biomolecules in the assembly and manipulation of nanoscale polymeric particles. Chem. Sci. 2012, 3, 1363-1380. [CrossRef] [PubMed]

77. Hu, J.; Zhang, G.; Liu, S. Enzyme-responsive polymeric assemblies, nanoparticles and hydrogels. Chem. Soc. Rev. 2012, 41, 5933-5949. [CrossRef]

78. Davis, M.E.; Chen, Z.; Shin, D.M. Nanoparticle therapeutics: An emerging treatment modality for cancer. In Nanoscience And Technology: A Collection of Reviews from Nature Journals; World Scientific: Singapore, 2010; pp. 239-250.

79. Maeda, H.; Nakamura, H.; Fang, J. The EPR effect for macromolecular drug delivery to solid tumors: Improvement of tumor uptake, lowering of systemic toxicity, and distinct tumor imaging in vivo. Adv. Drug Deliv. Rev. 2013, 65, 71-79. [CrossRef]

80. Gao, L.; Zheng, B.; Chen, W.; Schalley, C.A. Enzyme-responsive pillar [5] arene-based polymer-substituted amphiphiles: Synthesis, self-assembly in water, and application in controlled drug release. Chem. Commun. 2015, 51, 14901-14904. [CrossRef]

81. Brancato, V.; Gioiella, F.; Profeta, M.; Imparato, G.; Guarnieri, D.; Urciuolo, F.; Melone, P.; Netti, P.A. 3D tumor microtissues as an in vitro testing platform for microenvironmentally-triggered drug delivery systems. Acta Biomater. 2017, 57, 47-58. [CrossRef]

82. Wang, B.; Liu, H.; Sun, L.; Jin, Y.; Ding, X.; Li, L.; Ji, J.; Chen, H. Construction of high drug loading and enzymatic degradable multilayer films for self-defense drug release and long-term biofilm inhibition. Biomacromolecules 2017, 19, 85-93. [CrossRef] [PubMed]

83. Huang, J.; Shu, Q.; Wang, L.; Wu, H.; Wang, A.Y.; Mao, H. Layer-by-layer assembled milk protein coated magnetic nanoparticle enabled oral drug delivery with high stability in stomach and enzyme-responsive release in small intestine. Biomaterials 2015, 39, 105-113. [CrossRef] [PubMed]

84. Van Hove, A.H.; Beltejar, M.-J.G.; Benoit, D.S. Development and in vitro assessment of enzymatically-responsive poly (ethylene glycol) hydrogels for the delivery of therapeutic peptides. Biomaterials 2014, 35, 9719-9730. [CrossRef] [PubMed]

85. Lee, J.; Ko, J.H.; Mansfield, K.M.; Nauka, P.C.; Bat, E.; Maynard, H.D. Glucose-Responsive Trehalose Hydrogel for Insulin Stabilization and Delivery. Macromol. Biosci. 2018, 18, 1700372. [CrossRef] [PubMed]

86. Lee, J.; Lin, E.-W.; Lau, U.Y.; Hedrick, J.L.; Bat, E.; Maynard, H.D. Trehalose glycopolymers as excipients for protein stabilization. Biomacromolecules 2013, 14, 2561-2569. [CrossRef]

87. Mancini, R.J.; Lee, J.; Maynard, H.D. Trehalose glycopolymers for stabilization of protein conjugates to environmental stressors. J. Am. Chem. Soc. 2012, 134, 8474-8479. [CrossRef] [PubMed]

88. Liu, Y.; Lee, J.; Mansfield, K.M.; Ko, J.H.; Sallam, S.; Wesdemiotis, C.; Maynard, H.D. Trehalose glycopolymer enhances both solution stability and pharmacokinetics of a therapeutic protein. Bioconjug. Chem. 2017, 28, 836-845. [CrossRef]

89. Messina, M.S.; Ko, J.H.; Yang, Z.; Strouse, M.J.; Houk, K.; Maynard, H.D. Effect of trehalose polymer regioisomers on protein stabilization. Polym. Chem. 2017, 8, 4781-4788. [CrossRef]

90. Pelegri-O'Day, E.M.; Paluck, S.J.; Maynard, H.D. Substituted polyesters by thiol-ene modification: Rapid diversification for therapeutic protein stabilization. J. Am. Chem. Soc. 2017, 139, 1145-1154. [CrossRef]

91. Chen, J.; Glaus, C.; Laforest, R.; Zhang, Q.; Yang, M.; Gidding, M.; Welch, M.J.; Xia, Y. Gold nanocages as photothermal transducers for cancer treatment. Small 2010, 6, 811-817. [CrossRef]

92. Moon, G.D.; Choi, S.-W.; Cai, X.; Li, W.; Cho, E.C.; Jeong, U.; Wang, L.V.; Xia, Y. A new theranostic system based on gold nanocages and phase-change materials with unique features for photoacoustic imaging and controlled release. J. Am. Chem. Soc. 2011, 133, 4762-4765. [CrossRef] [PubMed]

93. Duan, Z.; Cai, H.; Zhang, H.; Chen, K.; Li, N.; Xu, Z.; Gong, Q.; Luo, K. PEGylated Multistimuli-Responsive Dendritic Prodrug-Based Nanoscale System for Enhanced Anticancer Activity. ACS Appl. Mater. Interfaces 2018, 10, 35770-35783. [CrossRef] [PubMed]

94. Kashyap, S.; Singh, N.; Surnar, B.; Jayakannan, M. Enzyme and Thermal Dual Responsive Amphiphilic Polymer Core-Shell Nanoparticle for Doxorubicin Delivery to Cancer Cells. Biomacromolecules 2015, 17, 384-398. [CrossRef] [PubMed] 
95. Hervault, A.; Dunn, A.E.; Lim, M.; Boyer, C.; Mott, D.; Maenosono, S.; Thanh, N.T. Doxorubicin loaded dual $\mathrm{pH}$-and thermo-responsive magnetic nanocarrier for combined magnetic hyperthermia and targeted controlled drug delivery applications. Nanoscale 2016, 8, 12152-12161. [CrossRef] [PubMed]

96. Li, H.; Liu, K.; Williams, G.R.; Wu, J.; Wu, J.; Wang, H.; Niu, S.; Zhu, L.-M. Dual temperature and pH responsive nanofiber formulations prepared by electrospinning. Colloids Surf. B Biointerfaces 2018, 171, 142-149. [CrossRef] [PubMed]

97. Davaran, S.; Ghamkhari, A.; Alizadeh, E.; Massoumi, B.; Jaymand, M. Novel dual stimuli-responsive ABC triblock copolymer: RAFT synthesis,"schizophrenic" micellization, and its performance as an anticancer drug delivery nanosystem. J. Colloid Interface Sci. 2017, 488, 282-293. [CrossRef] [PubMed]

98. de Solorzano, I.O.; Alejo, T.; Abad, M.; Bueno-Alejo, C.; Mendoza, G.; Andreu, V.; Irusta, S.; Sebastian, V.; Arruebo, M. Cleavable and thermo-responsive hybrid nanoparticles for on-demand drug delivery. J. Colloid Interface Sci. 2019, 533, 171-181. [CrossRef] [PubMed]

99. Wang, X.; Zhang, J.; Wang, Y.; Wang, C.; Xiao, J.; Zhang, Q.; Cheng, Y. Multi-responsive photothermal-chemotherapy with drug-loaded melanin-like nanoparticles for synergetic tumor ablation. Biomaterials 2016, 81, 114-124. [CrossRef] [PubMed]

(C) 2019 by the authors. Licensee MDPI, Basel, Switzerland. This article is an open access article distributed under the terms and conditions of the Creative Commons Attribution (CC BY) license (http://creativecommons.org/licenses/by/4.0/). 